\title{
Contemporary Philosophical and Ethical Fights over Jews, Judaism, and the State of Israel
}

In recent decades, Jews in Europe could hardly complain about a lack of public attention regarding Jewish history, culture, and especially Israel. In general, European mainstream media is covering lots of news, trends, biographies, and conflict-ridden stories with a direct or indirect reference to Jewish issues. It might easily be that the excessive attention nowadays paid to Jews in Europe is part -and syndrome-of the still existing abnormality in the relations between Jews and non-Jews on the "old continent," seventy-five years after the Shoah. Probably it could fill books, academic workshops, and university semesters to analyze the chosen topics and the specific forms of reporting when Jews are of interest in the media.

In the academic field, things do not look much different, especially not in Germany. We have experienced a real "boom” of Jewish Studies, Israel Studies, Yiddish and Hebrew language courses especially during the 1990s. To make it quite clear: I do not want to discredit this massive interest in Jewish issues in re-unified Germany-on the contrary. Especially in East Germany, there were a lot of things to make up for conveying profound and objective knowledge on modern Jewish History, Israel and the Middle East conflict-after forty years of anti-Israeli propaganda in the former G.D.R. It is my feeling that during the past twenty-five years, we have been able to do a lot in Germany, in the academic field, to educate future scholars, publishers, journalists, teachers or even diplomats, all of whom have developed a notable understanding of Jewish religion and history, of Jewish rituals and customs, of dreams and visions, and of course also of the Jewish dilemmas and traumata across the centuries. I am convinced this is the best way of prevention against old and new forms of antisemitism.

It is an irrefutable fact that parts of the European societies in recent decades have developed enormous interest in studying and understanding the Jewish world as a whole-and this was, in general, not the case before the Second World War and the Shoah. Though, after World War II, at least some people in Europe asked the crucial question, why this old, allegedly highly educated, enlightened continent was, in fact, unable to avert the million fold genocide of the European Jews. They also had to realize that not a few, allegedly civilized nonJews from almost all countries occupied by the German “Wehrmacht” applauded 
when the Germans started their infamous "program of extermination"-or even joined forces with the Nazi thugs.

Collaboration with the German Nazis, and also excessive own riots against the local Jewish population in several European States under German occupation have finally become a subject of strong interest after World War II-and this makes a lot of sense for distinct reasons: First of all to clarify-or, at least to try to clarify-why a non-Jewish, mainly Christian population appeared as unable or unwilling of protecting a small minority of culturally and religiously "others" when the German killers and their allies entered the scene.

The relevant discussions went on for decades now, among scholars, academics, intellectuals, theologians, and others, also in Eastern Europe, and some coevals are convinced that the European self-conception has distinctly changed since World War II and the Shoah. This might, of course, also be a question of feeling guilt, but obviously not chiefly. It rather seems to be a question of reorientation and re-determination of one's own relations to the Jews.

Now we can speculate to what extent such a process of re-orientation and redetermination has really taken place, how many European non-Jews have really been involved and so on.

However, it is important to have these questions in mind when trying to understand how Jews and Jewish life are appearing in contemporary philosophy and ethics, and what these disciplines could have learned from the Shoah. Or, just to put it the other way around: What affects modern philosophy and ethics-in Europe and anywhere else around the globe-when still flirting with anti-Jewish and anti-Israeli ideas and imaginations, despite the Shoah?

Fortunately, both Jewish and non-Jewish philosophers and ethicists have been engaged in figuring out why relations between Jews and non-Jews drastically failed in Europe, at least until the middle of the twentieth century. Theoretical approaches might open now the doors for a better mutual understanding and future living together. Anyhow, the Shoah is present as a constant shadow, as an incurable break accompanying the past, present, and probably also the future in Europe.

Lars Rensmann described in our joint panel on "Philosophy and Ethics," how the Frankfurt School theorists, in particular Theodor W. Adorno, Max Horkheimer, and Leo Löwenthal, have dedicated a considerable part of their philosophical and analytical work on anti-Jewish politics and its implications for critical thinking after the Holocaust. In so doing, they have immensely contributed to our current understanding of modern antisemitism but also to critical ethics and politics of anti-antisemitism. Their ideas and analyses yet provide important 
resources for political and ethical responses to the ongoing, and once again resurgent, challenge of antisemitism. ${ }^{1}$

Eva-Maria Ziege, from her perspective, has brought to mind that actually the most important contributions of sociology given to research on antisemitism date back to the 1940s. Since the works of the exiled Frankfurt School, successive sociologies gained importance which have not substantially contributed to theory of antisemitism. ${ }^{2}$ But antisemitism has consistently updated and "modernized" itself, and a crucial question emerges: How can present sociology-without neglecting current theory formation-cope with the problem of antisemitism, beyond exclusively empirical research? Could it be that philosophy and other disciplines are currently overstrained to grasp the roots of new, "modernized" Jewhatred, especially when its creators are coming from academic spheres themselves?

We have quite popular philosophers and ethicists on stage now who criticize the established monotheistic religions-all of them!-for being intolerant, for allegedly speaking in absolute terms, for still confining people in their individual way of life and so on. These critiques might come along as general allegations, and this is nothing really new under the sun.

However, it makes, to my mind, a huge difference, when distinct critics of religion-philosophers, ethicists, psychologists, and others-start blaming religious representatives for "practicing barbarous rituals" to which in their mind, circumcision belongs. Olaf Glöckner has reflected on the so called "circumcision debate" in Germany in 2012-a distinctly "heated debate" where, aside from medical doctors, a considerable number of public figures argued against circumcision by applying ethical and moral points. The debate is yet brewing, in Europe in general. It was not the debate itself, as Glöckner mentioned, that has shocked the Jewish and the Muslim population in Germany but rather the radicalness of the attacks, the absolutization of "arguments" which made a factual discussion almost impossible. ${ }^{3}$

1 Cf. L. Rensman, "The Politics and Ethics of Anti-Antisemitism: Lessons from the Frankfurt School," lecture for the Panel Philosophy and Ethics, Conference “An End to Antisemitism!”, University of Vienna, Vienna, February 19, 2018.

2 Cf. E.-M. Ziege, "The Problem of Antisemitism and the Current Challenges for Political Sociology," lecture for the Panel Philosophy and Ethics, Conference "An End to Antisemitism!”, University of Vienna, Vienna, February 19, 2018.

3 Cf. O. Glöckner, "The 'Circumcision Debate' in Germany 2012-an Ethical Discussion?," lecture for the Panel Philosophy and Ethics, Conference “An End to Antisemitism!”, University of Vienna, Vienna, February 19, 2018. 
From there, also today it seems to be only a small transition to Jew-hatred and to mark Jews as the distinct "others." Critics of central elements of Jewish religion-though, not necessarily only of Jewish religion-often claim to act according to high ethical values, referring to moral categories of the western World but denying their own anti-Jewish attitude. Critique of the circumcision of Jewish and Muslim infants and of kosher butchering are favored starting points for scathing a religion like Judaism in general. As Monika Schwarz-Friesel, also in our joint panel, vividly described by means of examples again from Germany, camouflaged anti-Jewish stereotypes are "better" accepted in discourse than open hostility against Jews, but as such, they are much more dangerous. Using philosophical argumentation patterns and the strategy of self-legitimization, educated critics of Judaism call upon values such as humanity and reason, protecting the individual and striving for world peace. "For the sake of all mankind" they demand the alteration of Jews, Judaism-and connected to this, the alteration of the Jewish state of Israel. ${ }^{4}$

However, this seems to be not only a German or European but also a global phenomenon and as such, fatally underestimated. Regarding a massive and polarizing criticism on Israeli politics in general that sometimes even flows into delegitimization of the State of Israel, strange to say, some renowned Jewish intellectuals are noticeably involved.

A notable recent example is Omri Boehm. Boehm, a very young Jewish philosopher born in Israel, having lived in Germany for a while, but teaching now in New York, published a well-received essay in The New York Times on March 9, 2015, titled: "The German Silence on Israel, and its Cost." In this essay, he sharply criticized prominent German intellectuals like Jürgen Habermas for-as he worded it-“the reluctance to speak critically about Israel.” Indeed, Boehm wrote that he could understand a general German intellectuals' hesitation in commenting and assessing Israeli politics- "because of German responsibility for the crimes of the Holocaust." However, this did not hinder Omri Boehm to go so far to conclude: "When intellectuals like Jürgen Habermas and Günter Grass fail to speak out, they are stepping into a familiar, and dangerous, trap." 5

4 Cf. M. Schwarz-Friesel, "Referring to Ethical Values in Contemporary Discourse of Educated Antisemites: Empirical Data from a Corpus Study (2010 - 2017),” lecture for the Panel Philosophy and Ethics, Conference “An End to Antisemitism!”, University of Vienna, Vienna, February 19, 2018.

5 O. Boehm, “The German Silence on Israel, and Its Cost," The New York Times, March 9, 2015, https://opinionator.blogs.nytimes.com/2015/03/09/should-germans-stay-silent-on-israel/. 
Notwithstanding that Günter Grass, in fact, took a very critical position against Israel in his disputed poem "Was gesagt werden muss" ["What Needs to Be Said"] in 2012, ${ }^{6}$ a lot of questions remain regarding Omri Boehm's accusation against Habermas and his colleagues.

First of all: Who defines when a philosopher has to intervene in day to day politics? And what is the "guideline"-which countries and politics, which conflicts and human rights abuses have to be on top of the agenda? Boehm is lamenting on the "German intellectuals silence" regarding present Israeli politics as "dangerous"-but what happens, when the voices keep silent regarding Russia's Crimes on the Crimea, China's human rights violations in Tibet, “American Guantanamo,” and Assad's gas attacks against his own Syrian population?

But Omri Boehm goes further in his criticism-something really seems to plague him. In an interview with Deutschlandfunk, a well-established, public German radio channel, he stated that Zionism could not be compatible with humanistic values. ${ }^{7}$ In this interview, of course, Boehm is responding to the locking up of the "Jewish character" of the State of Israel, pushing the question "either-or" ("entweder-oder"): Either a Jewish state-or, as the other option-a "democratic, liberal” state but without a Jewish imprint.

In fact, Omri Boehm "indicates" that Zionism is, in his mind, not compatible with humanistic values. Should this mean, in reverse conclusion, that the Zionist movement has a distinct inhuman imprint, and is unacceptable for modern and enlightened people? I do not feel as the right person to rate the impacts of Omri Boehm's critique on Habermas and his colleagues, and also not the social impacts of his statement regarding "incompatibility" of Zionism and humanistic values. Boehm, however, says he loves his home country (Israel) but explains that he is very worried about its future. I tend to believe him at this point. On the other hand, his moral radicalism might easily invite misinterpretation and denigration of the whole national Jewish project.

And so once more, the current State of Israel is considered the biggest obstacle for possible peace between Israelis, or better: between Israeli Jews, and Palestinians. From there, it seems only a small step to overemphasize the IsraeliPalestinian conflict as one of the biggest trouble spots in the Middle East, and

6 Cf. G. Grass, "Was gesagt werden muss," Frankfurter Allgemeine, April 4, 2012, https://www. faz.net/aktuell/feuilleton/debatten/das-israel-gedicht-von-grass/das-gedicht-von-guenter-grasswas-gesagt-werden-muss-11707985.html.

7 N. Freundel, “'Zionismus nicht vereinbar mit humanistischen Werten'. Der Philosoph Omri Boehm im Gespräch mit Natascha Freundel,” Deutschlandfunk, February 8, 2015, https:// www.deutschlandfunk.de/philosoph-omri-boehm-zionismus-nicht-vereinbar-mit.1184.de.html? dram:article_id=306399. 
to consider it as the central issue of the whole region. At least since the failed "Arab spring" and the extremely violent, fanatic and ideologically heated civil wars which appeared following autocratic regimes for example in Libya, Egypt, Syria, and Yemen, we witness that the whole region is shaken by much worse problems.

However, also among leading intellectuals, including keen thinkers like Noam Chomsky, the perception predominates that former Colonial Empiresand nowadays more or less "exclusively" the USA-would be mainly responsible for the actual outbreak of civil wars and excessive massacres even among civil population. We find such "steep theses" also among European intellectuals, but Noam Chomsky is probably the most idolized thinker who merges an allegedly disastrous American Middle East policy together with special American-Israeli interests, good food for new "conspiracy theorists."

It might be debatable to what extent such an overemphasis on Israel's allegedly destructive impacts on the whole Middle East is just a naive by-product of intellectual analysis, of moral and especially radicalism, or indeed of philosophical hypocrisy. Chomsky is not alone in the Jewish group of icons of America's New Left pulling Israel to pieces. Judith Butler might be seen as specific example of this strange intermixture of ideological premises, moral radicalism, starryeyed-and yes, maybe even dangerous-admiration of different cultures and rigorous damnation of Israel. For Butler, as Berkeley philosopher of post-structuralism well-esteemed around the globe, it is "extremely important" to have "understanding (for) Hamas, Hezbollah as social movements that are progressive, that are on the Left, that are part of a global Left."8

Who wonders then, that Butler is also a supporter of the international Boycott, Divestment and Sanctions movement against Israel, the BDS? Interestingly, she is also very popular in Germany, and in September 2012, she was even awarded the prestigious Theodor Adorno Prize in Frankfurt am Main. There was, of course, protest by Jewish organizations, but without effect.

A little curiosity might illustrate Judith Butler's-and other intellectuals'loss of reality when exclusively fixed on criticizing the politics of the State of Israel. Butler is in favor of a binational State of Jews and Palestinians with an Arab majority, that would, of course, mean the end of the Jewish State. However, especially wondrous is Butler's justification for such a proposal. In her book Parting Ways: Jewishness and the Critique of Zionism she seriously tries arguing that

8 P. Marquardt-Bigman, "Judith Butler and the Politics of Hypocrisy," The Jerusalem Post, August 30, 2012, https://www.jpost.com/Blogs/The-Warped-Mirror/Judith-Butler-and-the-politicsof-hypocrisy-365385. 
"the loss of demographic advantage for the Jewish population in Israel would surely improve prospects for democracy in that region." Again we might speculate whether Judith Butler's views on the history, "nature," and future perspective of the State of Israel are ideologically blurred or ethically over-coded, or just the result of ivory-tower exercises far away from the factual developments in the world.

The same question makes sense when confronting ourselves with Noam Chomsky. It is indisputable that Chomsky is one of the worldwide most molded intellectuals on the left, and in some aspects on the far left. Chomsky is renowned for his harsh criticism on both American and Israeli politics for the last fifty years. He is brilliant in certain analyses of power politics and fatal political dependencies. People from very different backgrounds, ages, and cultures do stream to his lectures and disputations.

However, it seems that Chomsky has undergone a certain kind of radicalization in his critiques on Israel, over the years. Since 2008, he has supported the "Free Gaza Movement" calling it "a courageous and necessary endeavor."10 And in 2013, Chomsky was one of the renowned academics who called on Stephen Hawking to boycott the prestigious international "Facing Tomorrow"-conference in Jerusalem-“successfully," as we know. ${ }^{11}$

Later on, in an interview with Amy Goodman for "Democracy Now," Chomsky went so far to say: "Israel's actions in Palestine are much worse than apartheid in South Africa." 12 In face of this statement, it seems appropriate to remember the bloodshed in Soweto in 1976-just one of the huge white crimes of violence with about 500 casualties among children and teenagers. Or the townships and the fences where people of all ages died by thirst or starvation behind. ${ }^{13}$ However, there are also statements by Noam Chomsky that reveal a dan-

9 J. Butler, Parting Ways: Jewishness and the Critique of Zionism (New York: Columbia University Press, 2012), 210.

10 "Who We Are," Free Gaza, accessed February 11, 2019, https://www.freegaza.org/about-us/ who-we-are/.

11 Cf. Y. Skop, “Top Scientist Joins BDS Movement: Stephen Hawking Confirms He Is Boycotting Israeli Conference,” Haaretz, May 8, 2013, https://www.haaretz.com/hawking-confirms-israelboycott-1.5241535; R. Booth and H. Sherwood, "Noam Chomsky Helped Lobby Stephen Hawking to Stage Israel Boycott,” The Guardian, May 10, 2013, https://www.theguardian.com/world/2013/ may/10/noam-chomsky-stephen-hawking-israel-boycott.

12 "Noam Chomsky: 'Israel's Actions in Palestine Are much Worse than Apartheid' in South Africa,” Democracy Now, August 8, 2014, https://www.democracynow.org/2014/8/8/noam_chom sky_what_israel_is_doing.

13 Cf. e.g. M. Gallagher, “The Birth and Death of Apartheid,” BBC News, June 17, 2002, http:// news.bbc.co.uk/2/hi/africa/575204.stm. 
gerous underestimation-or minimization?-of objective threats: For example, when he compares Israel and Iran in their respective striving for regional power. In March 2015, Chomsky said in a TV disputation with Ezra Levant: "Israel has invaded Lebanon five times. Iran hasn't invaded anyone."14

Also in the spring of 2015, Chomsky gave an interview with euronews, and despite Barack Obama's strong efforts of that time to reach a Nuclear Deal with Iran, Chomsky said: "There are two states who cause disaster in the Middle East, by permanently carrying out aggressions, violence, terroristic and illegal acts. Both are atomic States with giant arsenals of nuclear weapons." ${ }^{15}$ Chomsky referred to the United States and Israel as nuclear states heavily feared by the rest of the world, and in the converse argument he showed, again, a lot of empathy for Iran and understanding for its efforts also to reach the status of an Atomic power. Chomsky indeed claimed in the same interview that

\begin{abstract}
Iran has very small military spending, even in terms of the region, not to mention those of the United States. The strategic doctrine of Iran is defensive, just conceptualized in a way, that an attack can be repelled until diplomacy will intervene successfully. But the United States of America and Israel, the two rogue states, don't want to tolerate this kind of determent. No strategic analyst with half a brain would think that Iran would ever use a nuclear weapon [...] There is no indication that the ruling clerics-whatever we think about themwould be interested in destroying everything they possess. ${ }^{16}$
\end{abstract}

It is well known that Noam Chomsky, a longstanding professor at the MIT, brilliant linguist and author of about 100 books, had offered extreme positions already many years before. But in case of the Iran, it becomes, especially in recent years, a kind of risky dimension when one of the biggest intellectual icons of the global Left-and, not to forget, a Jew-starts to whitewash the Iranian Islamic Regime in its criminal efforts.

One might find different descriptions and explanations for such a loss of reality. And even presumed, the "argument" of unconditional self-defense might contribute to the ambitious Iranian atomic program - what about the Iranian "export" of terrorism around the globe? It seems to be a great (Western) delusion that the Islamic Regime in Iran is "only" a threat for the Middle East region.

14 E. Levant, "EXCLUSIVE: Ezra Levant and Noam Chomsky clash on Israel, anti-semitism (Part 3 of 3),” The Rebel Media, March 8, 2015. https://www.therebel.media/exclusive_ezra_le vant_and_noam_chomsky_discuss_israel_and_anti_semitism_part_3_of_3.

15 "Noam Chomsky: 'Die USA sind ein Schurkenstaat, Europa ist extrem rassistisch'," euronews, April 17, 2015. https://de.euronews.com/2015/04/17/noam-chomsky-die-usa-sind-einschurkenstaat-europa-ist-extrem-rassistisch.

16 Ibid. Translation by the author of this article. 
Its secret operations are meanwhile traced in quite different countries-including today's Germany-and not to forget those tens of thousands of Iranian soldiers and officers meanwhile fighting for Assad in Syria, in line with Russian troops, not that far from the Israeli borders.

But back to Noam Chomsky and his demonizing view on American and Israeli politics on the one hand, and the apology of current Iranian politics on the other. Where are reasons to identify one with the other? Is it, we might ask, the ideological factor in his mind that puts the world upside down? Or is it, first of all, a compulsive demand to make the Western World guilty for all evil? Or, at the end of the day, also politics of hypocrisy?

The impression would be totally wrong that the notorious anti-Israel-critiques by today's philosophers would just be an exclusive American-or even American-Jewish-problem. Although, the remarkable number of outstanding American intellectuals and publicists who also directly stricture to current Israeli politics-including prominent names like Peter Beinart, Norman Finkelstein, and Max Blumenthal-might raise the question whether there's a special sense of mission, however justified.

Of course, on other continents, we find similar voices attacking Israel, sometimes similarly provoking, and sometimes in a rather hidden or subtle way. Thus, in the aftermath of 9/11, German philosopher Peter Sloterdijk reversed George W. Bush's "nomination" of Middle-Eastern "rogue states" and claimed that the United States of America and Israel would be "the real rogue states." 17 The main critique: Israel and the United States are, in Sloterdijk's eyes, playing their own games, regardless of any consequences.

Until now, I have mainly focused on critical philosophical voices against Israel and the United States. Though, if we turn to the ethical civic voices-or, at least, to those who are considered as distinct ethical voices-we cannot bypass the churches in Europe. For years, we note church congresses decisively paying special attention to the Palestinian "Nakba" in 1948 but without explaining in detail what had just caused the Independence War of 1947/48. At the same time, church events focus especially on human rights violations by Israeli military or police but do not mention subtle or open efforts of Palestinian forces to develop effective terrorist structures (like the obsessive digging of terrorist tunnels from Gaza and Lebanon).

The remarkable European Christian solidarizing with the Palestinians in Gaza and the West Bank often goes hand in hand with new forms of political ac-

17 “'Schurkenstaat USA': Sloterdijk holt aus,” n-tv Germany, September 25, 2002. https://www. n-tv.de/archiv/Sloterdijk-holt-aus-article121474.html. Translation by the author of this article. 
tivism. On the organizational level, there are indications that anti-Israel attitudes could become a common denominator at least for some of the Christian congregations. For example, in the Fall of 2013, the Methodist Church in Britain launched an online survey among its members to determine whether the Church should support the "Boycott, Divestment and Sanctions movement" (BDS) or not. ${ }^{18}$ Among the Christian theologians, in view of the unsolved Israeli-Palestinian conflict, some have obviously fallen back into anti-Israel clichés which are easily discernible as anti-Jewish. Thus, the German protestant theologian Jochen Vollmer wrote in the prestigious Deutsches Pfarrerblatt [German Pastor's Journal] already in 2011:

We, the Christians of Germany, cannot theologically compensate our untold guilt toward the Jews by considering the state structure of the people of Israel as a sign of God's loyalty; [a state] which has made hundreds of thousands of innocent people victims and continues to do so. ${ }^{19}$

In consequence, Vollmer denied the Jewish State of a Christian (theological) recognition, because of its (allegedly) inhuman behavior.

This is what I would describe as a kind of "ethical correctness" primarily taking care for the Palestinians as an ethno-cultural minority group that is mostly the loser in a subtly or openly proceeding asymmetric conflict (at least so in Israel).

In the future, it would be worthwhile to explore to what extent Christian churches and especially their local communities are indeed willing to join political forces with an anti-Israel line of attack-like the BDS-but to what extent they are also sensitized for recently expelled Christians from Middle East "frontier" states around Israel.

To sum up: Our panel on "Philosophy and Ethics" has clearly shown, that there is-in our days-a special attention on Jewish issues, at least in Europe, more or less in equal parts "distributed" on Jewish life on the old continent and the wider Diaspora, on the one hand, and on Israel on the other. In principle, public attention might gratify such a small ethno-cultural and ethno-religious minority in Europe, like the Jews, especially since there are indicators

18 Cf. "Boycott, Divestment and Sanctions Briefing," The Methodist Church, accessed February 11, 2019, https://www.methodist.org.uk/our-work/our-work-in-britain/public-issues/peace making/israel-palestine/boycott-divestment-and-sanctions-briefing/.

19 J. Vollmer, "Vom Nationalgott Jahwe zum Herrn der Welt und aller Völker. Der Israel-Palästina-Konflikt und die Befreiung der Theologie,” Deutsches Pfarrerblatt 111, no. 8 (2011): 409. Translation by the author of this article. 
that European civic society has altered its attitudes towards Jews and Judaism after World War II and the Shoah. However, it appears as highly questionable, when non-Jewish philosophers, intellectuals, theologians and other key figures of Western society blame Jews (and in some cases also Muslims) for allegedly "practicing barbarous rituals" (as circumcision and kosher butchering) without engaging in a factual discussion with Jews on-site. It appears, however, also highly questionable when Jewish-born icons of the New Left in the USA undertake exceptionally sharp attacks on modern Israel and its politics, possibly ready to delegitimize the State of the Jews. Thus, while some of the left-wing Jewish intellectuals-like Omri Boehm-argue in a kind of moral sense, other celebrities-like Judith Butler and Noam Chomsky-evidently operate with clearly abstruse comparisons, thus supplying "argumentation aid" for Jew-haters across all political camps. A plausible intellectual explication of this (inner-)Jewish phenomenon is still missing.

Julius H. Schoeps is Professor emeritus for German-Jewish History at the University of Potsdam. Since 1992, he has been the Director of the Moses Mendelssohn Center for European Jewish Studies in Potsdam. His main foci of research are German-Jewish History; History of Zionism; Intellectual History and Jewish Enlightenment; Migration from Eastern Europe since 1989; History of anti-Semitism as well as Nazi Looted Art and Christian-Jewish relations.

\section{Bibliography}

Boehm, Omri. "The German Silence on Israel, and Its Cost." The New York Times, March 9, 2015. https://opinionator.blogs.nytimes.com/2015/03/09/should-germans-stay-silent-onisrael/.

Booth, Robert, and Harriet Sherwood. "Noam Chomsky Helped Lobby Stephen Hawking to Stage Israel Boycott.” The Guardian, May 10, 2013, https://www.theguardian.com/world/ 2013/may/10/noam-chomsky-stephen-hawking-israel-boycott.

Butler, Judith. Parting Ways: Jewishness and the Critique of Zionism. New York: Columbia University Press, 2012

Free Gaza. “Who We Are.” Accessed February 11, 2019. https://www.freegaza.org/about-us/ who-we-are/.

Freundel, Natascha. “'Zionismus nicht vereinbar mit humanistischen Werten'. Der Philosoph Omri Boehm im Gespräch mit Natascha Freundel.” Deutschlandfunk, February 8, 2015. https://www.deutschlandfunk.de/philosoph-omri-boehm-zionismus-nicht-vereinbar-mit. 1184.de.html?dram:article_id=306399.

Gallagher, Michael. "The Birth and Death of Apartheid." BBC News, June 17, 2002, http:// news.bbc.co.uk/2/hi/africa/575204.stm. 
Glöckner, Olaf. “The 'Circumcision Debate' in Germany 2012-an Ethical Discussion?” Lecture for the Panel Philosophy and Ethics, Conference "An End to Antisemitism!” University of Vienna, Vienna, February 19, 2018.

Grass, Günther. “Was gesagt werden muss.” Frankfurter Allgemeine, April 4, 2012. https:// www.faz.net/aktuell/feuilleton/debatten/das-israel-gedicht-von-grass/das-gedicht-vonguenter-grass-was-gesagt-werden-muss-11707985.html.

Levant, Ezra. "EXCLUSIVE: Ezra Levant and Noam Chomsky clash on Israel, anti-semitism (Part 3 of 3)." The Rebel Media, March 8, 2015. https://www.therebel.media/exclusive_ ezra_levant_and_noam_chomsky_discuss_israel_and_anti_semitism_part_3_of_3.

Marquardt-Bigman, Petra. "Judith Butler and the Politics of Hypocrisy." The Jerusalem Post, August 30, 2012. https://www.jpost.com/Blogs/The-Warped-Mirror/Judith-Butler-and-thepolitics-of-hypocrisy-365385.

The Methodist Church. "Boycott, Divestment and Sanctions Briefing." Accessed February 11, 2019. https://www.methodist.org.uk/our-work/our-work-in-britain/public-issues/peace making/israel-palestine/boycott-divestment-and-sanctions-briefing/.

N.N. “Noam Chomsky: Israel's Actions in Palestine are 'Much Worse Than Apartheid' in South Africa." Democracy Now, August 8, 2014. https://www.democracynow.org/2014/8/8/ noam_chomsky_what_israel_is_doing.

N.N. "Noam Chomsky: 'Die USA sind ein Schurkenstaat, Europa ist extrem rassistisch'." euronews, April 17, 2015. https://de.euronews.com/2015/04/17/noam-chomsky-die-usasind-ein-schurkenstaat-europa-ist-extrem-rassistisch.

N.N. “'Schurkenstaat USA': Sloterdijk holt aus.” n-tv Germany, September 25, 2002. https:// www.n-tv.de/archiv/Sloterdijk-holt-aus-article121474.html

Rensman, Lars. "The Politics and Ethics of Anti-Antisemitism: Lessons from the Frankfurt School." Lecture for the Panel Philosophy and Ethics, Conference "An End to Antisemitism!", University of Vienna, Vienna, February 19, 2018.

Schwarz-Friesel, Monika. "Referring to Ethical Values in Contemporary Discourse of Educated Antisemites: Empirical Data from a Corpus Study (2010-2017)." Lecture for the Panel Philosophy and Ethics, Conference "An End to Antisemitism!", University of Vienna, Vienna, February 19, 2018.

Skop, Yarden. "Top Scientist Joins BDS Movement: Stephen Hawking Confirms He Is Boycotting Israeli Conference.” Haaretz, May 8, 2013, https://www.haaretz.com/hawkingconfirms-israel-boycott-1.5241535.

Vollmer, Jochen. "Vom Nationalgott Jahwe zum Herrn der Welt und aller Völker. Der Israel-Palästina-Konflikt und die Befreiung der Theologie." Deutsches Pfarrerblatt 111, no. 8 (2011): $404-9$.

Ziege, Eva-Maria. "The Problem of Antisemitism and the Current Challenges for Political Sociology." Lecture for the Panel Philosophy and Ethics, Conference "An End to Antisemitism!", University of Vienna, Vienna, February 19, 2018. 